\title{
Spanish Environmental Generations in the Twentieth Century
}

\author{
Manuela Caballero' \\ Department of Business Management and Sociology \\ University of Extremadura, Spain
}

\section{Abstract}

This article is an attempt to relate the concept of generation, as a variable that helps to explain certain environmental behaviors, with theories on intergenerational changes in values (Inglehart, 1977, 1991, 1998; Inglehart \& Flanagan, 1987). This theory predicts an increase in post-materialistic values in more developed societies, with ecology being one of these values. According to these forecasts, a greater ecological commitment should be expected from younger generations in developed societies, where material needs are covered. However, my data did not fit into predictions of this theory. On the contrary, there is evidence of an increase in values which could, in a certain way, be called low-cost post-materialistic, applying the term proposed by Diekmann \& Preisendörfer (2003).

Keywords: environmental attitudes, generations, intergenerational change, postmaterialistic values

\section{Introduction}

The research question that directs this work is: How are predictions regarding intergenerational changes of values related to the environmental behavior of Spanish generations? As a work hypothesis, which arises from the question, I consider: (1) if it is possible to identify contemporary Spanish generations and (2) if their collective environmental identity can be defined.

The answer to this question requires the existence of a previous generational model to apply the variables that determine a higher or lower environmental profile. That is why one of the fundamental theoretical components of this work is the generation theory, which is still rarely applied in sociology. The starting point for the construction of the generation model was the results of previous studies (Caballero, 2015; Caballero \& Baigorri, 2013), in which six contemporary generations were characterized and defined from historical, socioeconomic (according to the

1 Author contact: manuelacaballero@unex.es 
level of scarcity/abundance), and environmental (according to the expression of environmental values and behaviors) aspects; and from which only a small synthesis is shown.

This article consists of a wide theoretical framework that, in addition to the generations theory, includes an approximation to environmental attitudes and values systems as well as a synthesis of the post-materialistic values theory, especially regarding intergenerational value change predictions. The article continues with the method designed to answer the research question. To finish, the results are presented and the main conclusions that are drawn from them.

\section{An approximation to the generation theory}

Two schools of thought can be found at the origins of the sociological generation concept: the French positivist school and the German historicist school. The founder of the first, Auguste Comte, developed a lineal and mechanical generation concept based on the amount of time needed for one generation to substitute another: 30 years is the expected time for this to happen (Comte, 1839, p. 639). While the historicist school does not focus on the mechanical continuity and succession of generations, but on the lack of continuity in the way that each one affects the course of history (Dilthey, 1875), what is important for this school is the quality of what unites the members of one generation that has shared political, social, intellectual, or artistic events. This rupture with Comte's positivism introduces an almost unsolvable methodological difficulty, because the key is not objectively set in the "amount of time" needed to determine the change from one generation to another, but in identifying the influence that the life of individuals has on the shared social-historical "quality of experiences."

The proposals of the Spanish philosopher Jose Ortega y Gasset and the German sociologist Karl Mannheim posed a more systematic approach to the generational concept, which fueled philosophy, literary criticism, history, and sociology during the twentieth century. For Ortega y Gasset (1970), the definition of generation implies the coexistence of several generations during the same historical period, creating the need to differentiate between peers (of the same age) and contemporaries (living at the same time). He established the duration of generations as 15 years, and divided the life of generations into five 15 -year periods, which correspond to five vital moments (childhood, adolescence, early adulthood, adulthood, and old age). Each generation lives on two levels: "one consists in accepting and learning from older generations' previous experience, the other would be to let their own spontaneity flow" (Ortega y Gasset, 1970, p. 41). The vital spirit that encourages each generation depends on both of these factors. In historical terms, when there is homogeneity between what was received (inherited) and what the new generation creates, the generation lives in a "cumulative epoch." But when there are big differences between 
what is received and created, the generations live in "eliminatory" or "polemic" epochs, which Ortega y Gasset called "combat generations." The alternation between cumulative and polemic epochs, between older and younger generations, is the rhythm of history.

Mannheim (1993) created the generation concept, not so much from the date of birth, as from sharing a same generational situation, which is where a point in history and conditions for our existence are joined. The creation of a generational link means that the individual is affected by a lack of continuity in the historical process; these lacks of continuity are experienced during a phase in their lives when the socialization process is not completed and, therefore, individuals still have flexible ways of interpreting reality. But the process does not give rise to just one collective identity; it also depends on each person's position within the social arena, that is, the economic, social, and cultural conditions that they live in, "because it is they who decide their possible ways of acquiring experience and awareness" (Ghiardo, 2004, pp. 24-25).

The use that sociology has made of this concept has been scarce and irregular in time and its epistemology. Some authors (e.g., Bell, 1962; Lapassade, 1963; Riesman, 1965; Toffler, 1973; Wright Mills, 1961) have come close to the concept, managing it well with regard to what would be the richest and most creative sociological approach, but with a weak empirical foundation. The second type of approximation, with the intention of resolving the problems that the methodological issue raises, is connected to the life cycle (Abrams, 1970; Attias-Donfut, 1991, 2000; Devriese, 1989; Donati, 1999; Eisenstadt, 1956; Elder, 1998; Erikson, 1980; Lalive d'Épinay \& Cavalli, 2009; Ryder, 1965).

But taking the next step-going from theory to putting the concept into practice (operationalization) - is more complicated. Perhaps that is why it is one of the lower praxis sociological concepts in the history of sociology; in fact, we have to resort to other disciplines, such as history, to know of one attempt for a more systematic application, that by William Strauss \& Neil Howe $(1991,1997)$. These historians, in cross-disciplinary terms, reconnect all things that have been separated from the generation theory, reformulating it again and combining it with cyclical models, like those of the historian Arnold Toynbee or the sociologist Pitirim Sorokin.

In the United States, Strauss \& Howe (1991) identified generational cycles between approximately 80 and 100 years, consisting of four stages, each of approximately 20 years, which are repeated on a recurring basis. These four stages (called high, awakening, unraveling, and crisis) correspond to four collective identities (prophet, nomad, hero, and artist). The stages are identified on the basis of times of crisis and economic bonanza, and collective identities are adjusted to a greater or lesser presence of strong institutions and social order, which in turn allows a higher or lower dose of individualism, personal freedom, and new lifestyles. 
Strauss \& Howe's work is a primary source for the current study of generations, and its influence can be found in typologies that either develop or add to those divisions. In a few cases they are a result of the work of advertisers and marketing centers (Boschma \& Groen, 2006). Other sources, such as the Canadian Census Office, include modifications (national changes) to the number of cohorts (Canadá Statistique, 2011). In Europe the organizational analysis has been applied: Becker (1990) deals with leadership styles and Bontekoning (2008) analyzes generational conflict; other more recent works along the same line are by Haeger and Lingham (2013) and Hillman (2014).

\section{Generations in the Spain of today}

In the case of sociology, among the very few applications that have been created, Díez-Nicolás (2008) analyzed the shift toward post-materialistic values in Spanish society and the effects on behavior during elections; and in the case of anthropology, Feixa (1998) analyzed the evolution of Spanish youth.

The generation model used in this work has been developed by taking all the indicated limitations into consideration and accepting that its effectiveness should be confirmed by more in-depth studies. Caballero \& Baigorri (2013) discussed the potential of the concept and adapted the Strauss \& Howe model for the Spanish case. The qualitative (social, historical, and cultural) aspects have been focused on, which define certain features of the members' collective personality and the detail of the milestones that have identifiably "marked" the generations shown in Caballero (2015). Regarding the size of the generations, the 15-year cohort model has been taken from Ortega y Gasset (1970). The generational structure of the contemporary Spanish population is summarized in Table 1 and brief explanations of the sociohistorical milestones that define these generations follow.

Table 1. Contemporary Spanish generations in 2016

\begin{tabular}{|l|c|c|c|}
\hline Classification & Born between & $\begin{array}{c}\text { Age group } \\
\mathbf{2 0 1 1}\end{array}$ & $\begin{array}{c}\text { Age group } \\
\mathbf{2 0 1 6}\end{array}$ \\
\hline Silent generation & $1914-1928$ & $96-82$ & $101-87$ \\
\hline Francoist generation & $1929-1943$ & $81-67$ & $86-72$ \\
\hline Baby boomer generation (protest generation) & $1944-1958$ & $66-52$ & $71-57$ \\
\hline Generation X & $1959-1973$ & $51-37$ & $56-42$ \\
\hline Generation Y (millennials, Peter Pan) & $1974-1988$ & $36-22$ & $41-27$ \\
\hline Generation Z & $1989-2003$ & $21-8$ & $26-13$ \\
\hline
\end{tabular}

Source: Own elaboration. 


\section{Silent generation (1914-1928)}

With the European countries immersed in World War I, the Spanish economy entered a growth phase from provision of raw materials to the countries at war, but the benefits were not equally distributed; on the contrary, speculation made big fortunes at a time of high inflation and impoverishment of the population. The majority of people born at that time were illiterate and forced to work from a very early age. In this scarcity framework the younger generation became part of the masses of young people who lined up with the movements that were fought in the Spanish Civil War (1936-1939), trailing behind the previous generation. The trauma of war itself, plus the dictatorship that followed for almost half a century, converted this generation into a silenced generation, more than a silent one.

\section{Francoist generation (1929-1943)}

During this period, wartime children were born. During the full primary collectivization process, due to the Civil War, this generation lived in extreme situations. The violence and suffering of war and hunger and the defeated people's fear of political repression remained engraved on their minds. This was the first of the generations to be indoctrinated under Spanish Catholicism principles (Díez-Nicolás, 2008), but it was also the generation that transmitted the antebellum ideological polarization, which would be maintained throughout the lifetime of this generation. For some it would mean immediate access to power and to positions of political responsibility within the regime; others would work in underground movements, reorganizing banned political parties and trade unions. The latter would later become the protagonists and leaders during the process of transition to democracy, occupying high positions in the first democratic governments.

\section{Baby boomer generation (1944-1958)}

The children belonging to this generation suffered the worst effects of the postwar period (shortage and repression) as well as the small benefits that stemmed from the economic recovery and termination of the regime's international isolation (Díez-Nicolás, 2008). A minority went to university and many actively participated in juvenile movements opposing Franco's regime from the end of the 1960s, but breaking with the previous generation's ideological and organizational principles. Affected by changes after the 1968 student movement, they would embrace new ideologies, such as pacifism, feminism, environmentalism, and criticism of bureaucracy. 


\section{Generation X (1959-1973)}

This is the economic development generation (Díez-Nicolás, 2008). Children and young people grew up with more material and economic security than previous generations, although they were still educated in ideologies and traditional values. There is massive access to university in the 1980s and women were totally accepted in the labor market. Television (especially advertising) would be an essential element in the construction of this generation's collective ideology.

\section{Generation Y (1974-1988)}

Also known as millennials, the boomerang generation, or Peter Pan generation (Shaputis, 2004), they were affected by important sociostructural changes (transition to democracy). Children attended a secular educational system, eager for democratization and social experimentation, and as youngsters grew under the cover of new freedoms and a maturing welfare state. Users of the first personal computers and video games, they became compulsive fashion, music, and fast food consumers, rejecting the ideological polarization of earlier generations. But they reached the labor market in the middle of a crisis, blocked and with devalued rights, which delayed them from an independent living (Shaputis, 2004) and made them feel "outraged" (Feixa \& Nofre, 2013) because they did not get what they believed they had been promised.

\section{Generation Z (1989-2003)}

This generation is the result of opulence in a society with no material difficulties, marked by deeper social policies and the extension and expansion of rights. Individuals live in increasingly diverse families and management of multiculturalism is a daily challenge in their schools. They were socialized in conspicuous consumption and superfluous goods with high expectations, especially in the last cohorts, whose first socialization occurred in the middle of the economic bubble. As digital natives (Prensky, 2001; Tapscott, 1998) they adapted more quickly to new technologies than their parents did.

\section{Dialectic materialism - post-materialism}

One of the fundamental components of people's attitudinal systems are the values that change as the generations flow. The most accepted theory regarding this social change is by Inglehart (1977), which is about the empirical basis for the World Values Survey. The central hypothesis is simple: Western societies' value systems changed from materialistic values, which seek economic and personal security, to post-materialistic or expressive values, which give priority to the quality of life. These are more frequent in more developed societies, in social classes with better economic positions, and in younger generations. 
The intergenerational values change theory includes two hypotheses. The hypothesis of scarcity considers that "the priorities of an individual reflect the socio-economic environment: we give a greater subjective value to things when there is a relatively low availability" (Inglehart, 1998, p. 42). Therefore, in societies where material needs are satisfied, there is a greater probability of the appearance of other more self-expressive types of needs. The second hypothesis depends on a sociology principle, the socialization process that makes "social" pervade "the individual," gradually shaping the individual's subjectivity. This process is particularly intense during childhood and adolescence, when learning and life experiences crystallize and become part of individual personality structure (Erikson, 1980). Because of this, according to Inglehart (1977), changes in value systems are gradual and usually occur when a younger generation (socialized in a highly developed socioeconomic context) replaces an older generation (socialized in scarcity and deprivation) and becomes society's adult population. One could, therefore, expect to find large intergenerational differences between young and elderly people's values in developed societies.

Environmental values are among post-materialistic values, not only as awareness and concern for the environment (cognitive/evaluative), but also in mobilization and activism (praxis). My research seeks to verify if this prediction has indeed come into effect and whether more environmental values are found in younger generations.

\section{The problem of environmental attitudes}

Studying environmental attitudes and their conversion into environmental behavior poses a lot of problems. Most literature reflects the poor predictive ability of values regarding environmental behavior (Williams, 1974), although certain scales (Schwartz, 1977; Schwartz \& Howard, 1980) allow researchers to verify — to a limited extent—some connection between them (Stern et al., 1985; Thøgersen, 1996). In other approaches, some authors (Dunlap \& Catton, 1979; Dunlap \& Van Liere, 1978) recommend studying values and their influence on environmental concern. Others suggest changing the study of attitudes for that of lifestyle, sometimes linked to the concept of cultural capital (Rosa et al., 1988; Stern \& Aronson, 1984), and others linked to marketing (Boyd \& Levy, 1963; Corraliza et al., 2006; Corraliza \& Martin, 2000). And, finally, others criticize the use of environmental awareness as a term due to the difficulty in making the concept applicable because of its multidimensionality (Diekmann \& Preisendörfer, 1992) and they come to the conclusion that these are the costs related to environmental behavior which, to a large degree, determine it (Diekmann \& Preisendörfer, 1998, 2003). 


\section{Methodology}

The methodological design includes both quantitative and qualitative techniques. The main source was a survey conducted in 2012, in the region of Extremadura $(\mathrm{n}=1,932)$, among a sample of three-generation families (all of which included living grandparents). ${ }^{2}$ The sample was selected in a stratified way depending on the size of the place of residence and through stratified random routes. All members of the family unit above the age of 12 were interviewed. The sampling error for the assumption of simple random sampling for $p=q=50$ was $\pm 3.2 \%$ for the family sample and $\pm 2.2 \%$ for the sample of people, for a $95 \%$ confidence level. Many questions were consistent with those in the World Values Survey and other surveys about environmental attitudes, in order to create comparable variables.

To identify each generation's environmental profile three ratings were created that express individual degrees of relationship with the environment:

1. The environmental concern index comprised 15 questions related to global and local environmental problems. The answers were given different values for the responses "very concerned," "rather concerned," "not very concerned," and "does not know/does not answer."

2. The environmental engagement index consisted of 13 questions referring to 13 environmental conflicts and measured citizens' political commitment and active involvement in environmental conflicts on three levels: "know about the conflict," "have participated in it," and "recognize that environmentalists are right." These options were valued in terms of "yes" or "no" and coded with 0 and 1 respectively; the minimum and maximum values for each conflict are between 0 and 3 .

3. The environmental attitude index was created from 13 questions relating to everyday environmental behaviors including saving energy and water, reusing materials and objects, and separating wastes. Different values were given for the answers to the questions, depending on the level of involvement in environmental improvement: whether they are done "normally," "sometimes," "never," and "doesn't know/doesn't answer."

From the sum of the three indexes I created an index called general pro-environmental profile (GPP) that expresses survey participants' levels of concern, commitment, and environmental attitudes concisely, in just one term. This index ranges from 0 , representing the lowest environmental profile level, to 100, the highest proenvironmental profile.

2 The survey was conducted by the research group Análisis de la Realidad Social, Extremadura University. 
The fieldwork was completed by carrying out 46 semi-structured interviews with members of families consisting of three generations. The interviews were carried out separately, face to face, in the interviewees' homes, both in rural and urban areas. Following Taylor and Bogdan (1987), in qualitative research it is not important to seek representation of the whole population; what is important is the potential of each "case" in assisting the researcher in developing theoretical impressions regarding the social life of the area studied. Nevertheless, variables were taken into account in the selection of interviewees regarding sex, age, the family's socioeconomic situation, and family role (grandparents-grandchildren).

\section{Results}

\section{Socioeconomic characterization of the generations}

Table 2 contains the socioeconomic characterization of the generations studied. In evolutionary terms, improvement in family members' living conditions is obvious. Older generations have a low level of income and education; members of younger generations have a higher level of education and live with families who have medium or high incomes.

When assessing their ideological position (based on the standard left/right dichotomy, where the right is represented by positive values and the left by negative values), a strong lean toward the right is seen in older generations, while from Baby boomers the lean is more toward the left, although there has been a gradual decline in leanings from generation to generation.

In short, younger generations live with families with more resources, have a higher level of education, a greater cultural capital, and ideologically are situated in progressive positions. It is the developed society model that complies with the scarcity hypothesis predictions, where material needs (economy and security) are satisfied and where other kinds of post-materialistic needs are more likely to appear.

Table 2. Sociodemographic profile of the sample

\begin{tabular}{|l|c|c|c|c|c|c|c|}
\hline & $\begin{array}{c}\text { Silent } \\
\text { generation }\end{array}$ & $\begin{array}{c}\text { Francoist } \\
\text { generation }\end{array}$ & $\begin{array}{c}\text { Baby } \\
\text { boomers }\end{array}$ & $\begin{array}{c}\text { Generation } \\
\text { X }\end{array}$ & $\begin{array}{c}\text { Generation } \\
\text { Y }\end{array}$ & $\begin{array}{c}\text { Generation } \\
\text { Z }\end{array}$ \\
\hline Age \\
\hline Born between & $1914-28$ & $1929-43$ & $1944-58$ & $1959-73$ & $1974-88$ & $1989-2003$ \\
\hline Age group in 2011 & $96-82$ & $81-67$ & $66-52$ & $51-37$ & $36-22$ & $21-8$ \\
\hline Age group in 2016 & $101-87$ & $86-72$ & $71-57$ & $56-42$ & $41-27$ & $26-13$ \\
\hline $\begin{array}{l}\text { Female population } \\
\text { (\%) }\end{array}$ & 64.6 & 55.8 & 49.1 & 48.4 & 48.5 & 48.7 \\
\hline
\end{tabular}




\begin{tabular}{|l|c|c|c|c|c|c|}
\hline & $\begin{array}{c}\text { Silent } \\
\text { generation }\end{array}$ & $\begin{array}{c}\text { Francoist } \\
\text { generation }\end{array}$ & $\begin{array}{c}\text { Baby } \\
\text { boomers }\end{array}$ & $\begin{array}{c}\text { Generation } \\
\mathbf{X}\end{array}$ & $\begin{array}{c}\text { Generation } \\
\mathbf{Y}\end{array}$ & $\begin{array}{c}\text { Generation } \\
\mathbf{Z}\end{array}$ \\
\hline \multicolumn{7}{|l|}{ Study levels (\%) } \\
\hline $\begin{array}{l}\text { No education or } \\
\text { primary education } \\
\text { only }\end{array}$ & 96.7 & 93.5 & 67.2 & 25.0 & 12.9 & 44.7 \\
\hline High school & 0.0 & 4.2 & 14.5 & 37.2 & 40.5 & 52.1 \\
\hline University & 3.3 & 2.3 & 18.3 & 37.9 & 46.6 & 3.2 \\
\hline Income per month (\%) & 30.0 & 26.7 & 5.0 & 1.1 & 3.3 & 0.0 \\
\hline $\begin{array}{l}\text { Less than 600 } \\
\text { euros (€) }\end{array}$ & 53.3 & 41.1 & 34.6 & 14.5 & 15.4 & 8.0 \\
\hline 600-1,000€ & 6.7 & 17.1 & 32.6 & 38.8 & 45.0 & 30.5 \\
\hline 1,101-1,800€ & 10.0 & 12.8 & 17.1 & 35.2 & 30.3 & 43.9 \\
\hline 1,801-3,000€ & 0.0 & 2.3 & 10.7 & 10.4 & 5.9 & 17.6 \\
\hline More than 3,000€ & \multicolumn{7}{|l|}{} \\
\hline Ideology & +23.4 & +17.3 & -26.9 & -19.7 & -23.5 & -16.6 \\
\hline Inclination
\end{tabular}

Source: Own elaboration.

\section{Environmental generations}

Among the expressed values, which may be defined as materialistic or postmaterialistic values, I found ecological and pro-environmental values. In this section the environmental profile for each generation is analyzed by a combination of variables, which range from environmental image and individual responsibility for conservation, to the indicators mentioned in the methodology section.

A gradual change has been found in the environmental image that generations have (Table 3). With regard to the environmental representations of the interviewees, the bucolic-romantic view has declined, which identifies environment with pleasant green landscapes, and awareness is growing regarding the problems caused by industrial development. When respondents have to choose between dichotomous positions (economic development versus the protection of nature) it is surprising to find that, at the time of an economic crisis with high unemployment rates, there is no majority support for economic growth and employment, especially in younger generations, who are more seriously affected by unemployment. This proenvironment character in younger generations is confirmed when they are asked about individual responsibility regarding environmental degradation. The more recent the generations are, the greater their awareness regarding individual responsibility in these processes. Thus, these data seem to suggest a modification in theories about intergenerational value changes. 
Spanish Environmental Generations in the Twentieth Century

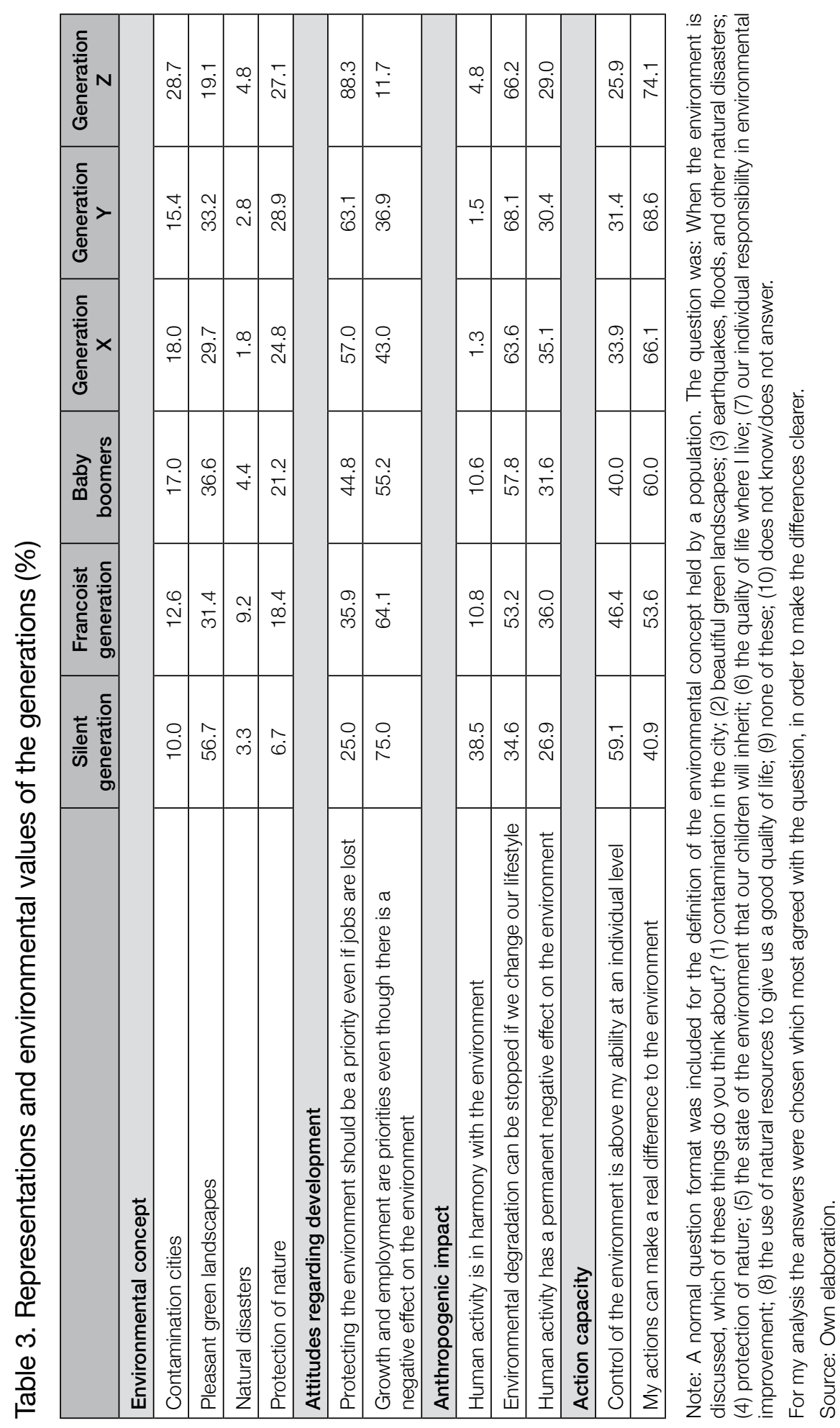




\section{Environmental indicators}

I have shown that environmental attitudes are not always consistent with what people put into practice and that people's habits and behavior cannot automatically be interpreted regarding environmental awareness, knowledge, and concern. This mismatch between thought and action can be examined more closely with the indicators created for this study.

Figure 1 shows the weight that different indicators have on the environmental profile of successive generations.

The index that measures habits related to waste separation, saving energy and water, and the recycling and reuse of materials and products (environmental attitude index) clearly appears to have more weight for all generations: Between $61 \%$ and $68.4 \%$ of the surveyed population say that they put these behaviors into practice. However, this indicator showed a rise in tendency throughout the generations, reached its peak in Generation X (68.4\%), then showed a decline in values in generations that followed.

Regarding a subjective concern for both global and local environmental problems (environmental engagement index; EEI) (climate change, biodiversity loss, use of pesticides, genetically modified organisms, noise pollution, etc.), a similar trend is observed, although in this index the highest proportion occurs in Generation $Y$ (48.1\% show concern), with a slight decline in Generation Z (45.1\%), which is the generation in which, according to Inglehart's thesis, more ecological awareness would exist.

Another similar trend is observed with activist commitment (EEI), measured by participation declared in environmental conflicts (attending protests, signing petitions, donations, environmental group membership, etc.). Once again my data contradict Inglehart's thesis when he says that "the materialistic-post-materialistic priorities evaluation has proven to be our best predictor of participation in both the ecologist and the pacifist movements" (Inglehart, 1991, p. 442).

Figure 2 summarizes this situation for the different generations in the general proenvironmental profile (GPP). The trend in GPP climbs from the Silent generation to Generation X and Generation Y, where it plateaus, and then declines slightly in Generation Z. All have a low environmental profile. Remember that the GPP moves between 0 and 100 - the highest value $(41.2 \%)$ does not even reach $50 \%$. The typical deviations show that the Baby boomer generation has the most representative average $(s d=10.5)$, while Generation $Z$ has the greater typical deviation $(s d=13.2)$. 


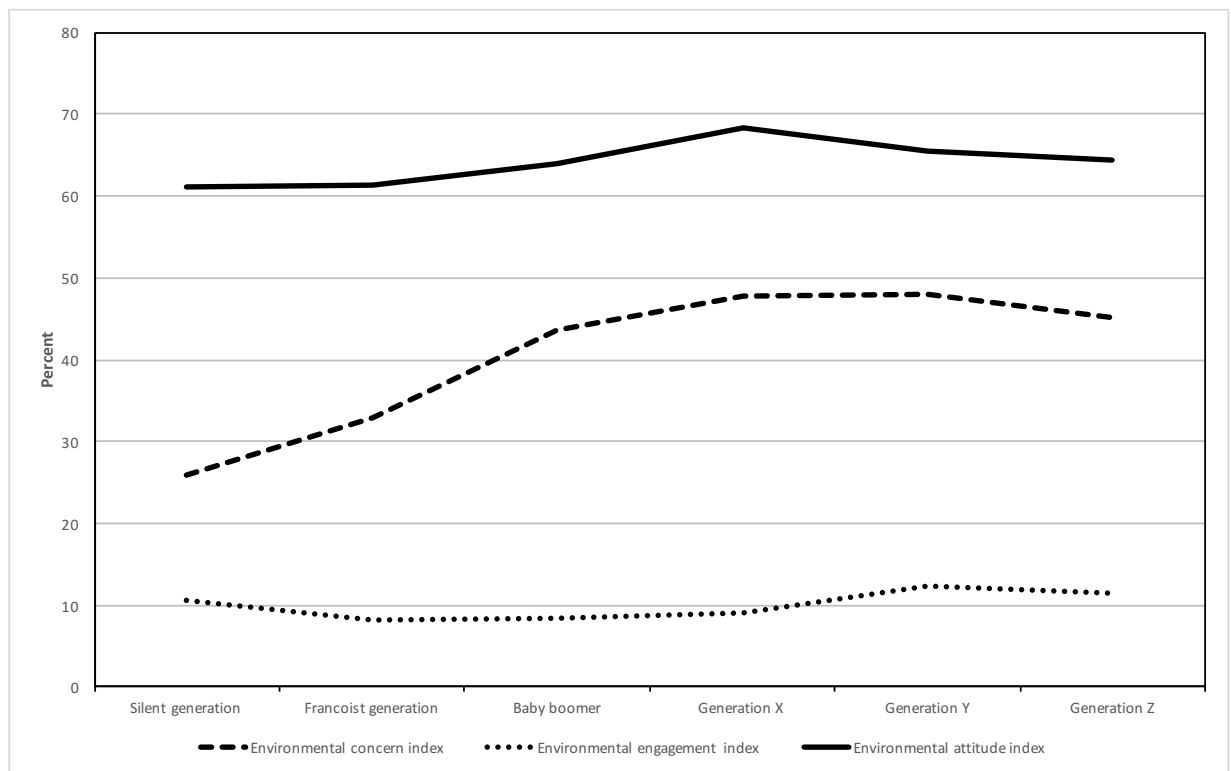

Figure 1. The weight of indicators in the environmental profile Source: Own elaboration.

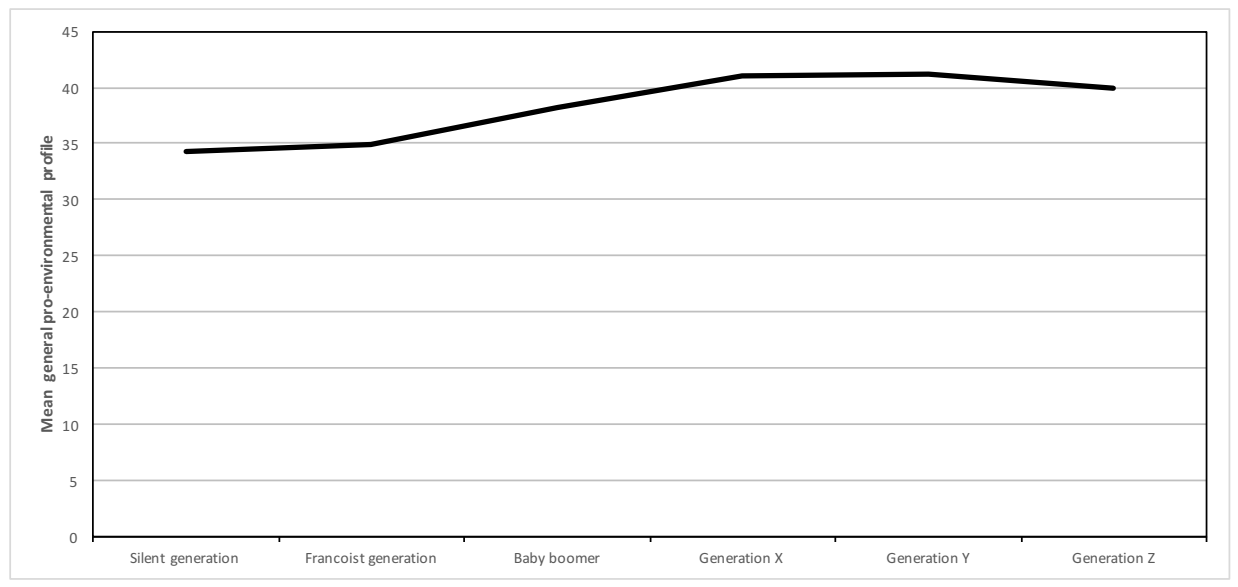

Figure 2. General pro-environmental profile

Source: Own elaboration. 


\section{Conclusions}

From the indicators and with the help of qualitative approximation based on the interviews, the environmental profile of the Spanish generations can be defined.

\section{Silent generation}

Socialized in scarcity, the Silent generation had behaviors based on saving and reduction in consumption, which had positive environmental effects, but which were not based on environmental ideologies. Therefore, this is a generation with no environmental awareness but with behaviors that indirectly have positive environmental effects. I call this environmental profile "materialistic base."

\section{Francoist generation}

Compared to the previous generation, there was an important increase in environmental concern without any big differences in socioeconomic socialization. But this greater concern for environmental problems is not translated into a greater political commitment and, together with maintaining savings habits and reducing consumption, similar to the previous generation, gives the impression that their behavior is very different from the post-materialistic values, even though this results in positive environmental effects. In the same way as the Silent generation, the Francoist generation's environmental profile is still based on materialism.

\section{Baby boomer generation}

Also called the protest generation, with the Baby boomer generation there was a turn to the left in the position of most of the country, which formed the backbone for large sociopolitical change. Socioeconomic improvements in living conditions (especially in the latest groups) and a rise in concern about environmental problems have not been expressed in the same way, neither in commitment nor in ecological activism, although there has been a rise in pro-environmental habits and behavior compared to the previous generation. Low militancy and political participation in the defense of environmental interests indicates that the habits and attitudes of Baby boomers are more the result of materialistic than post-materialistic values. In terms of environmental values, this is a "hinge" generation.

\section{Generation X}

Born in a time of full economic development and socialized with their basic needs satisfied, Generation X maintains the Baby boomers' positions, being the last generation to include all the indicators used in the analysis. Being to a certain degree the most post-materialistic of all, this is the generation which, to a greater extent, fits into Inglehart's theses. 


\section{Generation $Y$}

Generation $\mathrm{Y}$ is the first cohort born in democracy and socialized in favorable socioeconomic conditions. This is the first generation in which there is a noticeable decline in changes regarding expression of environmental values. If environmental behavior (environmental attitude index) increased in previous generations, albeit based on materialism, these attitudes decline in Generation Y; however, there is a significant rise in political-environmental commitment and activism. It is a generation that is marked not only by post-materialistic values, but also by postmodernism and the sociocultural implications: The major ideological proposals (including environmentalism) have no practical expression; they are like simple stories on the ideas consumer market. One must not miss any "interesting" mobilization if it fits with one's ideological spectrum, but without necessarily having to put it into practice in daily life. In Spanish we would be talking about a "just for show/phony" environmentalist generation.

\section{Generation Z}

The last few cohorts of Generation $\mathrm{Z}$ were born at a time of material opulence and conspicuous consumption. Their environmental behavior shows values which, far from being post-materialistic, are a little below those of generations immediately before them. Although they are globally "greener" than their parents and grandparents, their behavior is no more so than Generation X and Generation Y. Because of this decline in all of their environmental profile indicators, I call this the low-cost post-materialism generation, adapting the term first used by Diekmann and Preisendörfer (2003). That is to say, Generation $\mathrm{Z}$ have a pro-environmental awareness, but it is only applied to pro-environmental habits if there is a low or no cost.

\section{Discussion}

The generational analysis clearly shows how, with the arrival of new generations, their members come into society with a higher level of education, greater cultural resources, and a better socioprofessional situation. ${ }^{3}$ There are bases for material progress which represent the thesis by Inglehart on the appearance of postmaterialistic values and, with them, pro-environmental values.

\footnotetext{
3 I do not engage in the widespread debate over the past few years, which always reappears when there are economic crises: according to which, younger generations are going to be worse off than previous generations for the first time. Over long periods of time, the course of history systematically proves this to be wrong, but I have avoided this debate in my analysis.
} 
However, the environmental profile of generations shows disparities and inconsistencies between theory and practice, between ideological discourse and lifestyle, between attitude and behavior - to be precise, between what is said and what is done.

Therefore, while I find a more environmental way of thinking in more recent generations, at least statistically, this rise in awareness does not appear in effective environmental behavior, which is the opposite of intergenerational value change theory predictions. In terms of trends, the decline in environmental behavior among young people has been demonstrated in research conducted in other countries. This is the case in Grønhøj and Thøgersen (2009) when comparing environmental exchanges between parents and children in the United States (California) and Denmark. And Wray-Lake et al. (2010) found that younger generations in the United States are not as willing to endorse environmental behavior to the extent young people did during the decade of the 1970s. Of course we could consider a hypothesis arising from that, and assume that they may adopt different habits when they get older as a result of their socialization and cultural capital. But that would just be a hypothesis that would only be verifiable in the future.

The weight of the components (concern, commitment, and attitude) that make up the general pro-environmental profile also reveal interesting results that again create difficulties for the intergenerational value change requirements. First, because these components maintain a similar dynamism between them when, according to the theory, the younger the generations are, the bigger the changes one might expect. Second, and more importantly, my data show that it is possible to find behavior and habits with positive environmental effects that are not based on post-materialistic values.

\section{References}

Abrams, P. (1970). Rites de passage: The conflict of generations in industrial society. Journal of Contemporary History, 5(1), 175-190. doi.org/10.1177/ 002200947000500112

Attias-Donfut, C. (1991). Générations et âges de la vie. Paris: PUF.

Attias-Donfut, C. (2000). Rapports de générations: Transferts intrafamiliaux et dynamique macrosociale. Revue Français de Sociologie, 41 (4), 643-684. doi.org/ $10.2307 / 3322701$

Becker, H. A. (1990). Dynamics of life histories and generation research. In H. A. Becker (Ed.), Life histories and generations (pp. 1-58). Utrech: ISOR.

Bell, D. (1962). The end of ideology: On the exhaustion of political ideas in the fifties. Cambridge, MA: Harvard University Press. 
Bontekoning, A. C. (2008). Generatiegolven als vernieuwingsimpulsen: Over de verborgen kracht van generaties [Generation waves as renewable impulses: The hidden power of generations]. $M \& O, 1$ (January/February), 37-51.

Boschma, J., \& Groen, I. (2006). Generación Einstein: Más listos, más rápidos y más sociales. Comunicarse con los jóvenes del siglo XXI. [Einstein Generation: Smarter, faster and more social. Communicating with the youth of the twenty-first century]. Barcelona: Gestión 2000.

Boyd, H. W., Jr., \& Levy, S. J. (1963). New dimension in consumer analysis. Harvard Business Review, 41(6), 129-140.

Caballero, M. (2015). Transferencias ambientales intergeneracionales: Un análisis sobre abuelos y nietos [Intergenerational environmental transfers: An analysis of grandparents and grandchildren] (Unpublished doctoral dissertation). Universidad Pontificia de Salamanca en Madrid, Spain.

Caballero, M., \& Baigorri, A. (2013). ¿Es operativo el concepto de generación? [Is the generation concept operational?]. Aposta, 56, 1-45.

Canadá Statistique. (2011). Les générations au Canada. Âge et sexe. Recensement en bref. Retrieved from www12.statcan.gc.ca/census-recensement/2011/as-sa/98311-x/98-311-x2011003_2-fra.pdf

Comte, A. (1839). Course de philosophie positive. Tome Quatrième. Paris: Bachelier.

Corraliza, J. A., Berenguer, J., Moreno, M., \& Martín, R. (2006). La investigación de la conciencia ambiental: Un enfoque psicosocial [The investigation of environmental awareness: A psychosocial approach]. In the Ministry of Environment (Ed.), Persona, Sociedad y Medio Ambiente (pp. 105-120). Seville: Junta de Andalucía.

Corraliza, J., \& Martin, R. (2000). Medio ambiente y comportamiento humano [Environment and human behavior]. Revista Internacional de Sociología, 1, 31-56.

Devriese, M. (1989). Approche sociologique de la génération. Vingtième Siècle: Revue d'Histoire, 22(1), 11-16. doi.org/10.3406/xxs.1989.2123

Diekmann, A., \& Preisendörfer, P. (1992). Persönliches umweltverhalten. Diskrepanzen zwischen anspruch und wirklichkeit. Kölner Zeitschrift für Soziologie und Sozialpsychologie, 44, 226-251.

Diekmann, A., \& Preisendörfer, P. (1998). Environmental behavior: Discrepancies between aspirations and reality. Rationality and Society, 10(1), 79-102. doi.org/ 10.1177/104346398010001004 
Diekmann, A., \& Preisendörfer, P. (2003). Green and greenback: The behavioral effects of environmental attitudes in low-cost and high-cost situations. Rationality and Society, 15(4), 441-472. doi.org/10.1177/1043463103154002

Díez-Nicolás, J. (2008). Values and generations in Spain. In T. Pettersson \& Y. Esmer (Eds.), Changing values, persisting cultures (pp. 247-274). Leiden: Brill. doi.org/10.1163/ej.9789004162341.I-390.89

Dilthey, W. (1875). Über das studium der geschichte der wissenschaften vom menschen, der gesellschaft und dem staat.

Donati, P. P. (1999). Familias y generaciones. Desacatos, 2, 27-49.

Dunlap, R. E., \& Catton, W. R., Jr. (1979). Environmental sociology. Annual Review of Sociology, 5, 243-273. doi.org/10.1146/annurev.so.05.080179.001331

Dunlap, R. E., \& Van Liere, K. D. (1978). The "new environmental paradigm": A proposed measuring instrument and preliminary results. Journal of Environmental Education, 9(4), 10-19. doi.org/10.1080/00958964.1978.10801875

Eisenstadt, S. N. (1956). From generation to generation: Age groups and social structure. Glencoe, IL: Free Press.

Elder, G. H., Jr. (1998). The life course as developmental theory. Child Development, 69(1), 1-12. doi.org/10.1111/j.1467-8624.1998.tb06128.x

Erikson, E. H. (1980). Identity and the life cycle. New York, NY: Norton.

Feixa, C. (1998). De jóvenes, bandas y tribus [Of youth, bands and tribes]. Barcelona: Ariel.

Feixa, C., \& Nofre, J. (Eds.). (2013). \#Generación indignada: Topias y utopias del $15 M$ (Indignant generation: Topias and utopias of $15 \mathrm{M}$ ). Lleida: Milenio.

Ghiardo, F. (2004). Generaciones y juventud: Una relectura desde Mannheim y Ortega y Gasset [Generations and youth: A reinterpretation from Mannheim and Ortega y Gasset). Ultima Década, 20, 11-46. Retrieved from dialnet. unirioja.es/servlet/autor?codigo $=1055613$

Grønhøj, A., \& Thøgersen, J. (2009). Like father, like son? Intergenerational transmission of values, attitudes, and behaviours in the environmental domain. Journal of Environmental Psychology, 29(4), 414-421. doi.org/10.1016/j.jenvp. 2009.05.002

Haeger, D. L., \& Lingham, T. (2013). Intergenerational collisions and leadership in the 21st century. Journal of Intergenerational Relationships, 11(3), 286-303. doi.org/10.1080/15350770.2013.810525 
Hillman, D. R. (2014). Understanding multigenerational work-value conflict resolution. Journal of Workplace Behavioral Health, 29(3), 240-257. doi.org/10. $1080 / 15555240.2014 .933961$

Inglehart, R. (1977). The silent revolution: Changing values and political styles among western publics. Princeton, NJ: Princeton University Press.

Inglehart, R. (1991). El cambio cultural en las sociedades industriales avanzadas [Cultural change in advanced industrial societies]. Madrid: Centro de Investigaciones Sociológicas.

Inglehart, R. (1998). Modernización y posmodernización: El cambio cultural, económico y politico en 43 sociedades [Modernization and postmodernization: Economic and political cultural change in 43 societies]. Madrid: Centro de Investigaciones Sociológicas.

Inglehart, R., \& Flanagan, S. (1987). Value change in industrial societies. American Political Science Review, 81(4), 1289-1319. doi.org/10.2307/1962590

Lalive d'Épinay, C., \& Cavalli, S. (2009). Mémoire de l'histoire et appartenance générationnelle des personnes âgées. Gérontologie et Société, 3(130), 127-144. doi.org/10.3917/gs.130.0127

Lapassade, G. (1963). L'entrée dans la vie: Essai sur l'inachèvement de l'homme [Entry into life: An essay on the incompleteness of man]. Paris: Éditions de Minuit.

Mannheim, K. (1993). El problema de las generaciones [The problem of the generations]. REIS: Revista Española de Investigaciones Sociológicas, 62, 193-244. doi.org/10.2307/40183643

Ortega y Gasset, J. (1970). En torno a Galileo [Around Galileo]. Madrid: Revista de Occidente.

Prensky, M. (2001). Digital natives, digital immigrants. On the Horizon, 9(5), 1-6. doi.org/10.1108/10748120110424816

Riesman, D. (1965). Abundancia ¿para qué? [Abundance, what for?]. Mexico: Fondo de Cultura Económica.

Rosa, E. A., Machlis, G. E., \& Keating, K. M. (1988). Energy and society. Annual Review of Sociology, 14, 149-172. doi.org/10.1146/annurev.so.14. 080188.001053

Ryder, N. B. (1965). The cohort as a concept in the study of social change. American Sociological Review, 30(6), 843-861. doi.org/10.2307/2090964 
Schwartz, S. H. (1977). Normative influences on altruism. Advances in Experimental Social Psychology, 10, 221-279. doi.org/10.1016/S0065-2601(08)60358-5

Schwartz, S. H., \& Howard, J. A. (1980). Explanations of the moderating effect of responsibility denial on the personal norm-behavior relationship. Social Psychology Quarterly, 43(4), 441-446. doi.org/10.2307/3033965

Shaputis, K. (2004). El sindrome del nido lleno: Sobreviviendo el retorno de los hijos adultos [The full nest syndrome: Surviving the return of adult children]. Desorden Hadas Publishing.

Stern, P. C., \& Aronson, E. (Eds.). (1984). Energy use: The human dimension. New York, NY: W. H. Freeman.

Stern, P. C., Dietz, T., \& Black, J. S. (1985). Support for environmental protection: The role of moral norms. Population and Environment, 8(3), 204-222. doi.org/10.1007/BF01263074

Strauss, W., \& Howe, N. (1991). Generations: The history of America's future, 1584 to 2069. New York, NY: William Morrow and Company.

Strauss, W., \& Howe, N. (1997). The fourth turning: An American prophecyWhat the cycles of history tell us about America's next rendezvous with destiny. New York, NY: Broadway Books.

Tapscott, D. (1998). Growing up digital: The rise of the net generation. New York, NY: McGraw-Hill.

Taylor, S., \& Bogdan, R. (1987). Introducción a los métodos cualitativos de investigación. Barcelona: Editorial Paidós.

Thøgersen, J. (1996). Recycling and morality: A critical review of the literature. Environment and Behavior, 28(4), 536-558. doi.org/10.1177/ 0013916596284006

Toffler, A. (1973). El shock del futuro [Future shock]. Barcelona: Plaza y Janés.

Williams, R. M., Jr. (1974). Review of The nature of human values, by Milton Rokeach (New York, Free Press, 1973). Political Science Quarterly, 89(2), 399-401. doi.org/10.2307/2149267

Wray-Lake, L., Flanagan, C. A., \& Osgood, D. W. (2010). Examining trends in adolescent environmental attitudes, beliefs, and behaviors across three decades. Environment and Behavior, 42(1), 61-85. doi.org/10.1177/0013916509335163

Wright Mills, C. (1961). La imaginación sociológica [Sociological imagination]. México: Fondo de Cultura Económica. 
This text is taken from Human Ecology Review, Volume 23, Number 1, 2017, published 2017 by ANU Press, The Australian National University, Canberra, Australia.

dx.doi.org/10.22459/HER.23.01.2017.01 